\title{
EDGAR ALLAN POE AND THE TRADITION OF WESTERN MYSTICISM: A STUDY OF A SELECTION OF HIS SHORT STORIES
}

\author{
SEAWOMIR STUDNIARZ \\ University of Warmia and Mazury \\ slawomirstudniarz@wp.pl
}

Received 8 June 2018

Accepted 17 September 2018

\section{KEYWORDS}

Numinous, initiation pattern, transcendent vision, pantheism, Naturphilosophie, eschatological vision, epistemological, ontological, liminal, doctrine of stellification

\section{PALABRAS CLAVE}

Numinoso, patrón de iniciación, visión transcendente, panteísmo, Naturphilosophie, visión escatológica, doctrina epistemológica, ontológica, liminal de la estelificación

\section{ABSTRACT}

The article is devoted to the mystical elements and allusions surfacing in Poe's "analytical," "angelic," and "landscape" tales: "A Descent into the Maelström," "The Purloined Letter," "The Murders in the Rue Morgue," "The Domain of Arnheim," "Landor's Cottage," "Mesmeric Revelation," "The Colloquy of Monos and Una," "The Conversation of Eiros and Charmion," and "The Power of Words." It is argued that the narrative circumstances in "A Descent into the Maelström," in which the Norwegian fisherman describes to the unnamed narrator his adventure, rework the long-established spiritual imagery. The Dupin tales, in turn, are grounded in the cult of Night and in the initiatory powers of darkness, recalling the mystical "night of the soul." The two "landscape tales" depict the act of an artistic transcendence, performed by an artisan devoted to emulating the supernal order within the bounds of empirical reality. The article pays also due attention to the revelatory experience that results from crossing the boundary between the temporal and the eternal in Poe's "angelic" dialogues.

\section{RESUMEN}

Este artículo se centra en los elementos y alusiones místicos que afloran en los cuestos "analíticos," "angélicos" y "paisajistas" de Poe: "Un descenso al Maelström," "La carta robada," "Los crímenes de la 
calle Morgue," "El dominio de Arnheim," "La cabaña de Landor," "Revelación mesmérica," "El coloquio de Monos y Una," "La conversación de Eiros y Charmion," y El poder de las palabras. Se explica cómo las circunstancias narrativas de "Un descenso al Maelström," relato en el que un pescador noruego describe al narrador su aventura, se elaboran en base a un imaginario espiritual de larga tradición. Se explica, así mismo, cómo los cuentos de Dupin beben del culto a la Noche y a los poderes iniciáticos de la oscuridad, evocando la "noche del alma" mística. Se explica, además, cómo los dos "cuentos paisajistas" representan el acto de trascendencia artística ejecutado por un artesano dedicado a emular el orden celestial dentro de los límites de la realidad empírica. Por último, el artículo presta la debida atención a la experiencia reveladora que resulta del cruce de la frontera entre lo temporal y lo eterno en los diálogos "angélicos" de Poe.

Poe's narratives rooted in the conventions of the Gothic romance and displaying the essentially tragic view of the human condition are commonly regarded as his signature tales. Their protagonists are typically swallowed up into the vortex of incidents that transcend the boundaries of everyday existence and bring into sharp relief the human condition and the true nature of the universe, antithetical to man's aspirations and his well-being. Such tales explore various "boundary situations" and offer a consistently dark, unflinching view of human existence. Furthermore, the deepened subjectivity of narration compounded by the absence of a definitive final resolution carries specific epistemological implications, foregrounding doubt and uncertainty, charging the recipient with the daunting task of distinguishing between insinuations, if not delirious imaginings, of the protagonist's upset mind, and phenomena objectively occurring in the fictional reality. The shaping of the world presented underscores the destructive character of time and the horror of human transience; death is an absolute, terrifying, irreconcilable fact. The protagonists are often placed in narrow and suffocating spaces, with premature entombment, the most extreme version of physical confinement, as a foretaste of the ultimate and unsurmountable enclosure of the grave. Phenomenal reality is fundamentally polarized and reveals the immanent and fatal duality, duality which is not only experienced by Poe's characters but also internalized by them, which leads to their inner split, manifesting itself, for instance, as the perverse yearning for self-destruction, most vividly presented in the story "The Imp of the Perverse." 
In contradistinction to the characteristic sense of irrationality and mystery pervading the world presented in his Gothic fiction, some of Poe's tales show the vision of existence free from the tragic. They depict artistic, psychic or even truly otherworldly flights that enable the subjects to rise above the horror and chaos of human experience on the earth. These "mystical" explorations basically offer a delivery from the tragic sense of life, which is achieved by removing the fetters of the human condition and transgressing the limits of temporality and subjectivity. The release from the tragic primarily materializes in the revelatory experience that results from crossing the boundary between the temporal and the eternal, but it can be achieved also in the act of an artistic transcendence, performed by an artisan devoted to emulating the supernal order within the bounds of empirical reality.

The aim of the article is to explore the relation of the selection of Poe's tales, namely "A Descent into the Maelström," "The Purloined Letter," "The Murders in the Rue Morgue," "The Domain of Arnheim," "Landor's Cottage," "Mesmeric Revelation," "The Colloquy of Monos and Una," "The Conversation of Eiros and Charmion," and "The Power of Words," to the tradition of Western mysticism. Richard Jones in his book Mysticism Examined reserves the term "mysticism" for a specific type of experience and knowledge-claims resulting from it. Mystical experiences, he argues, "result from a process of turning one's attention inward and stilling all normal cognitive and emotional activities" (1). In his classic study The Varieties of Religious Experience, William James distinguishes four crucial marks of a mystical experience:

1. Ineffability: "it defies expression," "no adequate report of its contents can be given in words," and "it must be directly experienced; it cannot be imparted or transferred to others."

2. Noetic quality: mystical states are "states of insight into depths of truth unplumbed by the discursive intellect"; they are "illuminations, revelations."

3. Transiency. "Mystical states cannot be sustained for long."

4. Passivity: "the mystic feels as if his own will were in abeyance, and indeed sometimes as if he were grasped and held by a superior power" (380-381).

Furthermore, James emphasizes that consciousness of illumination is "the essential mark of 'mystical' states" (408) and that 
"the most important revelations are theological or metaphysical" (410). Jones divides mystical experiences into two types. What he calls a "nature-mystical experience" occurs when "sensory or other awarenesses remain present but the filters that our minds normally provide for ordering the content of awareness are significantly weakened or totally absent" (Jones 1). As a result, perception becomes "free from what mystics consider distortions, including conceptual frameworks, emotional attachments, and even a sense of self," and a "sense of unity overcomes our normal sense of a duality of subject and object" (Jones 1).

The second type of mystical experience, which Jones terms "a depth-mystical experience," arises "when the mind is completely stilled," and even though "There is no awareness of any object or of any content of any kind," yet "there is still a realization of an ultimate reality" (2).

James points to the "overcoming of all the usual barriers between the individual and the Absolute" as "the great mystic achievement" of all times; as he puts it, "In mystic states we both become one with the Absolute and we become aware of our oneness" (419). For James, this is the hallmark of a genuine mystical experience, transhistorical, not conditioned by culture:

This is the everlasting and triumphant mystical tradition, hardly altered by differences of clime or creed. In Hinduism, in Neoplatonism, in Sufism, in Christian mysticism, in Whitmanism, we find the same recurring note. (James 419)

By contrast, Patrick Grant in Literature of Mysticism in Western Tradition limits his focus specifically to Western mysticism, which he defines rather narrowly as "literature of mysticism in the Latin West," by which he means "a tradition extending, roughly, from St Augustine through the Western church of the Middle Ages, and into the modern scientific societies of Western Europe" (9). Arthur Versluis in Platonic Mysticism: Contemplative Science, Philosophy, Literature, and Art, offers a corrective to Grant's restrictive approach, by acknowledging the decisive impact of Plato and Plotinus on Western mysticism: "Once one recognizes that the history of mysticism in Christianity is actually the history of Platonic mysticism in European tradition, then one at once has an essential key" (Versluis 35). 
In order to support his central argument that "Throughout its history, European mysticism is informed by Platonism" (36), he quotes several distinguished scholars studying the history of Western mysticism, among them Emily Herman, who stated that "The great praeparatio mystica was Platonism, with its commanding intellectual sweep and its noble wonder and reverence," while Neoplatonism is "sweet and pure enough to be the main source and inspiration of the finest mediaeval and modern mysticism" (Versluis 36). Of particular importance is the attempt by Edward Ingram Watkin to develop "the metaphysic implicit in mystical experience, a philosophy of mysticism," and his formulation of the latter as "the body of truth about the nature of ultimate reality and of our relationship to it to be derived from the content of mystical experience" (Versluis 39). As formulated by Watkins, the philosophy of mysticism is particularly relevant for the purpose of the present article, which undertakes to bring to light its various traces, the "knowledge-claims" resulting from a mystical experience, scattered throughout the selection of Poe's tales subject here to analysis.

The use of the qualification "mystical" with reference to Poe's fiction may come as a surprise, especially when one considers his famous disparagement of Emerson as belonging to the contemptible class of "the mystics for mysticism's sake." As Ottavio Casale points out in his article "Poe on Transcendentalism," Poe "resented discourses which, aimed at the Sublime, fell into the Unknown and resulted only in obscurity of thought and language" (95). Poe indeed equated "mysticism" with "obscurity," but only mysticism in the sense of the "cant of seers" or self-styled transcendentalists. Yet, as Casale emphasizes, he did not deny "the legitimate pursuit of the supernatural by qualified minds [...] "highly sensitive or imaginative intellects' that can distinguish the Sublime" (95). The Italian scholar analyses Poe's complex and far from unequivocal attitude toward this literary and philosophical trend, highly influential in his time. Casale argues that Poe was "cognizant of two transcendentalisms, one which he considered to be sincere and 'ennobling,' and one which he thought to be the affectation of mimics and faddists," and he concludes that "Poe had no quarrel with the metaphysical substance of transcendentalism" (94-95).

Nevertheless, the issue of Poe's relation to mysticism has been contentious right from the start. His contemporaries seem to have been sharply divided on this point. For instance, James Russell Lowell declared quite emphatically that 
Mr Poe has no sympathy with Mysticism. The Mystic dwells in the mystery, is enveloped with it; it colors all his thoughts; it affects his optic nerve especially, and the commonest things get a rainbow edging from it. Mr Poe, on the other hand, is a spectator ab extra. He analyzes, he dissects, he watches. (Lowell 164)

Yet, William Gilmore Simms takes a diametrically opposite stance, pronouncing Poe "a writer of rare imaginative excellence, great intensity of mood, and a singularly mathematic directness of purpose," and concluding that "Poe is a mystic, and rises constantly into an atmosphere which as continually loses him the sympathy of the unimaginative reader" (200).

In the recent times resonances between Poe's work and various spiritual or esoteric systems have attracted the attention of several scholars. Leon Chai in his study The Romantic Foundations of American Renaissance notices in Poe's reading "a definite interest in Christian theory and apologetics," and points out Poe's knowledge of Tertullian, whose paradox from De Carne Christi is quoted in both Berenice and in the Marginalia (18). Chai states that "One may also observe the numerous scriptural references scattered throughout his tales and poems" (18). But, as he explains, Poe's theology is hardly orthodox, for, according to Chai, "he was much attracted to the doctrine of pantheism," which influenced "his conception of a cyclical process in which birth (or creation) represents a diffusion from the divine Spirit, death, the reabsorption or return into that Spirit" (18). Chai places Poe's cosmological system specifically in the classical tradition of emanationism, "in which the divine essence is viewed as a form of energeia, a creative and expansive energy that produces matter or things, and then descends into them, filling them with its own irradiating force" (275).

Stuart Levine, in his work Edgar Poe: Seer and Craftsman, claims that Poe was "a devout occultist" and his fiction is "a dramatization of his philosophical outlook" (162). Levine argues that "Poe believed in something very like the Oversoul, which, if not specifically divine, was clearly the source of an artist's inspiration," and as "one moves chronologically though Poe's work, this 'something' becomes more clearly divine and Poe comes to look more and more like an occultist" (164). In Levine's view, Poe's fiction is "a dramatization of an esoteric philosophy, one in which the artist is understood to be a 'seer,' in direct communion with some source of 
supernal inspiration" (165). Dolores Romero, in her article "El transfondo ocultista del cuervo: desde su simbolismo poético a los topoi modernistas," exploring the symbolism of the raven in Poe's ballad, points out the occult tradition behind his poetry. She notes the influence of the occult also on the poetry of William Blake, Friedrich Hölderlin, Gérard de Nerval, and their successors: Rubén Dario, Arthur Rimbaud, Rainer Maria Rilke and Ezra Pound (Romero 206). In her view, the history of modern poetry is linked to the hermetic doctrines of Emanuel Swedenborg and the gnosticism of Madame Blavatsky (Romero 206).

Randall Clack in his essay "'Strange Alchemy of Brain': Poe and Alchemy" addresses the question of the possible influence of alchemy on Poe's fiction, taking his cue from Barton Levi St. Armand's article "Usher Unveiled: Poe and the Metaphysic of Gnosticism," published in Poe Studies in 1972. Clack acknowledges Armand's contribution, but he undertakes to further his observations "in order to trace the influence of alchemical philosophy on both Poe and his work" (377). In his opinion, "Poe used the hermetic science to present, as St. Armand suggests for "The Fall of the House of Usher,' a unique metaphysic that draws heavily upon Renaissance hermeticism's science of alchemy" (Clack 377).

Among the assortment of recent studies of Poe's work relating it to various spiritual, esoteric or occult systems, there is only one text that deals specifically with the tradition of Western mysticism behind his writings. Dana Wilde in "Poe's Mysticism and the Eureka" recognizes the presence of "the Platonic and Neoplatonic strand of the perennial tradition," which in the author's view is particularly visible in his aesthetic theory, and also "in his long essay on cosmology, Eureka: A Prose Poem." Unfortunately, Poe's tales have been excluded here from the scope of inquiry. For Wilde the conclusive evidence for the mystical underpinnings of both Poe's aesthetics and his cosmology is the idea of unity. As he puts it,

In all mystical writings, efforts to describe or characterize the divine always come down to expressions of the unity of the cosmos, the oneness that is either the source or the common reality of all. [...] all is in All, and in Plotinus, all is seeking to return to the All.

The review of the scholarly efforts presented above prompts one conclusion: the relation between Western mysticism and Poe's fiction still remains a largely uncharted territory. Hence, with a view 
to partially filling the critical gap, in the ensuing sections of the present article this issue will be examined in a systematic way with reference to the specific tales. In order to effectively demonstrate the influence of the mystical traditions on the stories selected for scrutiny, analysis will focus on the shaping of the world presented and on the narrative circumstances in which the tellers deliver their stories. Metaphysical or mystical "prefigurings" in Poe's short fiction can be observed in "A Descent into the Maelström" and the detective tales. These belong to the so-called "analytical" tales, in which emphasis is placed on observation, reasoning, and deduction. In addition to the Dupin trilogy and "A Descent into the Maelström," this generic designation can also be applied to "The Gold Bug," "Thou Art the Man," and with some reservations to "Maelzel's Chessplayer."

The term "analytical tale" was first used by Clark Griffith in his 1954 article "Poe's 'Ligeia' and the English Romantics" as an alternative to the more established label "tale of ratiocination," which goes back to Poe himself. The latter first appeared in the unsigned review of Poe's Tales in the Aristidean, in October 1845. However, G. R. Thompson, in his "Note on the Texts" in the volume Edgar Allan Poe. Essays and Reviews, attributes the authorship of this review to Poe himself (1483). Gerard Sweeney, in his article "Beauty and Truth: Poe's 'A Descent into the Maelstrom'," even though his main emphasis is on the aesthetic aspect of the presented sea adventure, does recognize its ratiocinative or "analytical" quality:

Thus driven by his Sense of the Beautiful, the sailor stumbles on a visible order in the chaos of the Maelstrom, and so he makes his "three important observations" about the activity of spheres and cylinders (p. 190). In a way, his observations are based on reason, and so Robert Shulman is correct in linking the sailor to M. Dupin, who invariably succeeds through a combination of reason and imagination. (Sweeney 6)

In this "analytical tale," the Norwegian fisherman describes his adventure - the descent into the unplumbed depths of the sea, after his boat had been sucked into the monstrous whirlpool - to the unnamed main narrator on "the summit of the loftiest crag," "a sheer unobstructed precipice of black shining rock," protruding from the 
"lines of horridly black and beetling cliff" (II, 577-578). ${ }^{1}$ This elevation contrasts starkly with the depths of the sea vortex, the setting of the fisherman's adventure, and the two extremities encompass as it were the total range of human experience.

In the choice of the physical location in which the fisherman delivers his tale, one can discern a reference to the spiritual and mystical traditions, in which a mountain peak is often presented as the locus of theophany. In the Judeo-Christian religious tradition, the significance of mountains begins with the theophanies occurring on Mount Horeb and Mount Sinai. It was on the former mountain that God revealed himself as "I AM" to Moses, and through him to all the Israelites:

Moses crosses the desert and comes to the "mountain of God," Horeb. There he sees a "flame of fire coming from the middle of a bush" and hears himself called by name. A few moments later the voice of God comes to him, saying, "I am the God of your father, the God of Abraham, the God of Isaac, and the God of Jacob" (Exodus 3:6). Nevertheless, Moses senses that he is in the presence of an unknown aspect of the divinity, or even of a new god. (Eliade 179)

In more spiritual terms, Saint Teresa of Avila, in her writings quoted by James in The Varieties of Religious Experience, speaks of the "sublime summit" to which God raises the soul of a mystic (414). Particularly relevant, since it refers to both extremities present in Poe's story, is the remark made by the early Christian mystic Gregory of Nyssa, who in one of his homilies states that "the sublime voice of the Lord" is to him "as a mountain top to probe the mysteries of the unfathomed depths." 2

The reference to the mystical tradition puts the adventure of the Norwegian sailor in a new perspective. The clash with the overwhelming elements goes beyond the merely physical plane. The added spiritual, supernatural dimension is reinforced by the

\footnotetext{
${ }^{1}$ All the quotations come from the scholarly edition of Poe's works prepared by Thomas Olive Mabbott, The Collected Works of Edgar Allan Poe, vol. II and vol. III, Belknap Press of Harvard University Press, Cambridge 1978. They will be indicated by parenthetical references with the number of the volume and the page: (II, 577-578).

${ }^{2}$ Quoted in J. Tomkowski, Juliusz Słowacki i tradycje mistyki europejskiej, 32, footnote 50 (from A. Bober, Antologia patrystyczna, Kraków 1965, tom I, 128). [translation mine]
} 
presence of the rainbow stretched above the bottom of the gulf. Its appearance is interpreted by the sailor as "that narrow and tottering bridge which Mussulmen say is the only pathway between Time and Eternity" (II, 591). Thus, the precipitous gulf of the Maelström is transformed from the death pit into a kind of tunnel, leading from the temporal to the transcendental.

The watery funnel functions here as the liminal zone, separating two ontological domains. Manuel Aguirre offers an illuminating comment on the duality of space characteristic of Gothic fiction, but also present in many myths and fairy tales: he calls these two realms "the human domain of rationality and intelligible events" and "the world of the sublime, terrifying, chaotic Numinous which transcends human reason (but which need not be the supernatural)" (3). As he further notes, these two domains "are separated by some manner of threshold, and plots invariably involve movement from one site to the other - a movement which, most often, is presented as a transgression, a violation of boundaries" (Aguirre 3). Seen in this light, the chain of coincidences, the combination of the fisherman's reckless daring with the malfunction of his watch--the timing being his only safeguard against the onslaught of the tide--acquires a deeper significance. The experience, as befits the confrontation with Numinosum, could take place only because time, as measured by the watch, "stopped;" thus the protagonist was virtually transported beyond the realm of temporality.

The mystical undertones can also be observed in the relation between the fisherman, who tells the story of his personal encounter with the abyss, and his listener. The Norwegian sea wolf acts as a master or a teacher, who reveals to the narrator, a novice or a disciple, matters normally out of the reach of human mind and eye, in effect, using Gregory of Nyssa's words, initiating him "on the mountain top" into "the mysteries of the unfathomed depths." $\mathrm{He}$ owes his survival to the skills of observation, to his ability to analyze the movement of various objects within the whirlpool in relation to their shape, and to draw right conclusions. This attitude and the trust in the calculations of his mind proved salutary; yet the fisherman paid a high price for venturing beyond the limits of ordinary human experience. The brush with the Absolute left the indelible mark on his physical and mental being: "an event such as never happened before to mortal man" and "the six hours of deadly terror" broke him up "body and soul," and changed his hair "from a jetty black to white." 
The initiatory pattern in which the experienced and knowledgeable master instructs a largely ignorant disciple recurs in the Dupin trilogy. Especially in "The Murders in the Rue Morgue," the narrator assumes the role of an adept fascinated with the brilliant mind of his French companion. The two carry out their lives like a pair of veritable hermits:

Our seclusion was perfect. We admitted no visitors. [...] We existed within ourselves alone. It was a freak of fancy in my friend (for what else shall I call it?) to be enamored of the Night for her own sake; and into this bizarrerie, as into all his others, I quietly fell; giving myself up to his wild whims with a perfect abandon. (II, 532)

They form an exclusive society of Night-worshippers, indulging their predilection for "the sable divinity," as the narrator reverently calls the Night. They even go as far as "counterfeiting her presence" during the day, closing in the morning "all the messy shutters," "lighting a couple of tapers which, strongly perfumed, threw out only the ghastliest and feeblest of rays," and busying their "souls in dreams - reading, writing, or conversing, until warned by the clock of the advent of the true Darkness" (II, 532-533). Likewise, in "The Purloined Letter" the narrator and Dupin, gathered in the latter's library, sit and meditate in darkness, rarely addressing each other. As the narrator remarks at the beginning of the story, "For one hour at least [they] had maintained a profound silence; while each, to any casual observer, might have seemed intently and exclusively occupied with the curling eddies of smoke that oppressed the atmosphere of the chamber" (III, 974). However, upon the arrival of the chief of the Parisian police, the host "arose for the purpose of lighting a lamp, but sat down again, without doing so," when the prefect stated the purpose of his visit, which was to ask Dupin's opinion "about some official business." As the detective himself explains, "If it is any point requiring reflection [...] we shall examine it to better purpose in the dark" (III, 975). The idiomatic meaning of the phrase "in the dark" is brought into play, referring to the condition of ignorance, of not knowing, and the term "reflection" used by Dupin can be understood as both "careful or long consideration or thought" or, elaborating on the optical sense, "throwing light upon the matter."

The ritual-like quality of the gathering in Dupin's library is suggested not only by the darkness of the room. The dense tobacco 
smoke could be seen as the equivalent of incense burnt during religious services, and by offering the pipe to the prefect, the detective invites the Parisian official to join them in their ceremony, in the ritual of initiation into the workings of the human mind, into unraveling its secrets. These narrative circumstances prompt the conclusion that in the detective tales blackness is revalorized, rehabilitated - darkness no longer terrifies or foreshadows disaster; now it emerges as the environment suited to cognition, conducive to insight into the essence of things.

However, the significance of this cult of Night and of the initiatory powers of darkness cannot be fully grasped without recourse to the concept of "night of initiation" and its symbolism. Jan Tomkowski observes that in the European tradition a mystical journey usually involves passing through darkness, and he compares God to "an artist using the principle of chiaroscuro," as the night of the soul not only purifies but also "prepares the mystic for receiving the light, divine illumination" (54). Maria Janion, the Polish author of the study on the Romantic aesthetics Czas formy otwartej, argues that the myth of initiation is central to the whole Romantic enterprise, as the blueprint for comprehending and ordering human existence, and investing it with a higher significance. This myth manifests itself variously, as a journey or pilgrimage guided by the Master, the death of an "old man" and the subsequent rebirth, the motif of the road sometimes presented as a labyrinth, a journey through the night toward light; hence the night in the vaults as a favorite symbolic representation of the initiate's ripening, and the moment before sunrise as the destined moment of the longed-for transfiguration (Janion, Czas formy otwartej 14-15).

Under these terms, the French detective could be viewed as a high priest, a messenger mediating between the divine and the human worlds, an oracle delivering truths unto the feeble-minded. The narrator in "The Murders in the Rue Morgue" notes the duality of Dupin's mind, "the creative and the resolvent," and highlights the composite nature of the French detective: when he discloses to the narrator people's inner secrets, he falls into a kind of trance, and he seems inspired or possessed: "His manner at these moments was frigid and abstract; his eyes were vacant in expression; while his voice, usually a rich tenor, rose into a treble which would have sounded petulantly but for the deliberateness and entire distinctness of the enunciation" (III, 533). Commenting on Dupin's "trances," Halliburton states that this "might be a description of Roderick 
Usher as his consciousness tunes itself to the harmonies of a world beyond the gulf, or of Vankirk, the character in "Mesmeric Revelation" who communicates with that world and reports on it to the man who has placed him in the mesmeric state" (244). For Halliburton, this is "one way in which the 'beyond' gets into the tales of detection" (244).

Yet Dupin's powers are not supernatural; they do not transcend the human condition, and the narrator interprets his friend's seemingly extraordinary intuition and insight as "the result of an excited, or perhaps of a diseased intelligence" (III, 533). Besides, Dupin's revelations concern criminal mysteries that only seem inexplicable. Despite the supernatural aura that surrounds the gruesome murders of Madame L'Espanaye and her daughter, the fictional reality in this story, and in the other two Dupin tales, is endowed with a meaningful and rational order, so that it can be grasped and explained by reason. In each of the examined cases, Dupin exposes to the narrator the train of his thoughts, his way of reasoning and solving the crime; thus, in keeping with the initiatory pattern, he acts like a master introducing his disciple into the arcane knowledge.

In the detective tales, the triumph of ratio over the horror and chaos of existence and the concomitant cognizability of the world are achieved owing to the postulated continuity of the rational mind and the reality exterior to it, and by reducing Nature to the status of "a readable text." However, it is only in a comprehensive transcendent vision that the natural order can be truly surmounted. In the resulting artistic or spiritual vision, the human condition is blessedly cancelled and the limitations of the earthly existence happily overcome. In Poe's stories this is first achieved by "bringing the heavens down to the earth," owing to a visionary artist whose medium and field of activity at the same time is a landscape garden. Such artistic creation offers a glimpse of a higher, spiritual reality, thus anticipating a mystical vision par excellence. As David Ketterer aptly notes, "the landscape garden should convey to an earthly view the same impression that a heavenly being would receive looking at God's universe. To live within such a landscape is to experience a sense of the after-life" (208).

In "The Domain of Arnheim," the protagonist is "a landscape gardener" who transforms Nature into a work of art expressive of his creative design. His very name, Ellison - "son of Eli," that is "son of God," "Eli" meaning "God" in Hebrew (Kopaliński 208) - shows his 
affinity with the heavenly sphere, and as his brief existence on the earth attests, his home is in the supernal realm. Ellison undertakes the task of an artistic exaltation of Nature, aiming to embody the transcendent vision in empirical reality. Thus, Halliburton's remark that "Ellison happily subscribes to philosophical materialism, and the idea that nature should be improved by the application of human genius" (357) is off the mark.

The elevation of the material world depicted in "The Domain of Arnheim" is close to "the justification of Nature," a new trend in Western mysticism, whereby the natural world is perceived as "the garment of the Divine Spirit." Rufus Jones in the chapter titled "Valentin Weigel and Nature Mysticism" in his vast study Spiritual Reformers in the 16th and 17th Centuries observes that for German mystics of the sixteenth and seventeenth century:

One indwelling Life, one animating Soul, lives in and moves through the whole mighty frame of things and expresses its Life through visible things in manifold ways, as the invisible human soul expresses itself through the visible body. Everything is thus, in a fragmentary way, a focus of revelation for the Divine Spirit, whose garment is this vast web of the visible world. (144)

Tomkowski states this idea in the following way:

in the works of Boehme and Weigel the idea of renouncing the world for the sake of the divine is no longer contemplated. Nature not only provides Man with a shelter, but it also complements the Godhead, housing the Godhead or even supplying a material body for the divine essence. $(228)^{3}$

In Poe's story, the final effect of the artist's labors "conveys the sentiment of spiritual interference" (III, 1276), and the completed work assumes the air of "an intermediate or secondary Nature - a Nature which is not God, nor an emanation of God, but which still is Nature, in the sense that it is the handiwork of the angels that hover between man and God" (III, 1276).

\footnotetext{
3 "W tekstach Weigla czy Böhmego nie ma już mowy o ucieczce od świata do boskości. Natura jest nie tylko schronieniem człowieka, lecz także dopełnieniem Boga, jego mieszkaniem, a nawet materialnym ciałem dla boskiej esencji." [translation mine]
} 
The image of Ellison's dwelling presented at the end is quite revealing, conveying the sense of a transcendent vision of rare beauty in the depiction of "a mass of semi-Gothic, semi-Saracenic architecture, sustaining itself by miracle in mid-air, glittering in the red sunlight with a hundred oriels, minarets, and pinnacles; and seeming the phantom handiwork, conjointly, of the Sylphs, of the Fairies, of the Genii, and of the Gnomes" (III, 1283). In the names of these purported designers and artificers Halliburton notices the note of "onomastic heightening" (361). This linguistic elevation parallels the concomitant transmutation of the eponymous "domain" into the "Paradise of Arnheim."

The "Paradise of Arnheim" is situated in a remote, almost inaccessible area, hidden from the world at large. The usual approach was by the "stream that took a thousand turns" (III, 1279), the boat carrying the visitor had "threaded the mazes of this channel" (III, 1279), and "the windings became more frequent and intricate, and seemed often as if returning in upon themselves" (III, 1279). Similarly, in the story "Landor's Cottage," subtitled "a pendant to "The Domain of Arnheim," the path leading to the beautiful estate, as the narrator observes, "was so serpentine, that at no moment could [he] trace its course for more than two or three paces in advance" (III, 1330). Clearly, such descriptions contribute to spatial disorientation and emphasize the narrators' loss of the sense of direction, suggesting also that the two localities exist beyond the limits of phenomenal reality; they emerge as "worlds unto themselves" governed by the laws established by their creators.

The description of the lake in "Landor's Cottage," whose banks rounded off "into the clear heaven below," creates the impression of the optical descent of the sky. This motif is also present in "The Domain of Arnheim," not only in the "inverted heaven" reflected in the waters. In this story, the boat carrying the narrator is "dropped down, as if from heaven, into a circular basin" (III, 1280); moreover, the narrator admits that at the sight of the duplicated "drapery of the most gorgeous flower-blossoms [...] it became, indeed, difficult not to fancy a panoramic cataract of rubies, sapphires, opals, and golden onyxes, rolling silently out of the sky"(III, 1280). This optical illusion is consistent with the underlying conception of the descent of the heaven, of anchoring the transcendent vision in the material world.

The motifs discussed so far, surfacing in the Dupin trilogy, "A Descent into the Maelström," "Landor's Cottage," and "The Domain of 
Arnheim," foreshadow the mystical bent that takes full shape in the fictional explorations of the spiritual realm, in the stories referred to as "angelic dialogues" or "post-mortem reveries," that is, "Mesmeric Revelation," "The Colloquy of Monos and Una," "The Conversation of Eiros and Charmion," and "The Power of Words." The term "angelic dialogue," rooted in Biblical studies, has gained currency in Poe studies. As a generic label it is used, for instance, by Richard Kopley in Edgar Allan Poe and the Dupin Mysteries, or by Jerome McGann in The Poet Edgar Allan Poe: Alien Angel. As regards the other term, "post-mortem reveries," Kenneth Silvermann explains that it refers to tales in which "departed spirits return to earth or solemnly converse after death about their experiences while passing to the Other Side," and these tales are Poe's "version of the popular visionary fiction of the day that reported scenes and dialogues in heaven" (7).

In the first of these, "Mesmeric Revelation," insight into a higher, extra-sensual reality is gained owing to hypnosis and paranormal perception, while "The Colloquy of Monos and Una" and its companion piece "The Conversation of Eiros and Charmion" hinge upon survival of physical death and preservation of individual identity and consciousness in the after-life. In the last of these "mystical" tales, "The Power of Words," the unraveling of the mysteries of the universe takes place in the course of post-mortem initiation into the secrets of a new, heavenly existence.

These fictional epistemological and ontological speculations stem from the very foundations of the Romantic philosophy and art. Jeffrey Cox defines the whole Romantic movement as "in large part a project to discover for the individual an identity - an indivisible harmonious selfhood - that unites all of his faculties but also links him to other men and to the world around him" (19). He mentions the desired state of "anti-self-consciousness," which usually involves "a breakthrough into an imaginative realm where the divisions within the self and between the self are healed" (Cox 19). Romantics eagerly embraced pantheism, wherein, according to Peyre, the universe was perceived as one huge being in perpetual motion, ceaselessly striving to live more intensely, to become more and more aware of itself (225). The French scholar also lists such characteristic Romantic strivings as "spontaneous Platonism," "the urge to fuse plurality and oneness, to find a permanent and solid foundation underlying the stream of fleeting phenomena," as well as those voiced especially by German Romantics, "the longing to merge 'I' and 'not-I,' the temporal and the eternal" (Peyre 177). In the United States, as Chai points out, with 
Ralph Waldo Emerson the nature of the divine substance becomes identified with the infinite consciousness of the perceiving subject, whereas for Melville, as for Coleridge before him, the pantheistic principle of the "one Life within us and abroad" reveals the presence within consciousness of the same energy which animates the external Nature (12).

The distinguishing trait of the Romantic thought was the conception of the history of mankind and of the universe as one ongoing evolutionary process, and the inescapable corollary to that view - that the earthly life and the comprehensive history needed a complement, a culmination in a higher, spiritual realm. As Janion puts it, "the development of the spirit is not a closed cycle, contained within the earthly history. Its crucial stage, both in the life of an individual and in the history of mankind, must be enacted in the next world." 4

In "Mesmeric Revelation," "the glimpse of the afterlife," "the peek into the beyond" is afforded by the experiment during which a dying man is put under hypnosis. In this peculiar condition the mind pierces the veil of death, because it "perceives, with keenly refined perception, and through channels supposed unknown, matters beyond the scope of the physical organs" (III, 1030). Seo-Young Jennie Chu, in her article "Hypnotic Ratiocination," explains the difference between mesmerism, otherwise known as "animal magnetism," and hypnotism. She argues that whereas the former "signifies a cohesive physical fluid," the latter refers to "a psychological phenomenon, a function of suggestibility, demonstrating the influence of one human will upon another," yet by the time "Poe encountered it, however, mesmerism had already begun to take on the psychological connotations we now associate with hypnotism" (6).

Chu quotes extensively from Robert Fuller's Mesmerism and the American Cure of Souls, and among six distinct stages of mesmeric experience distinguished by Fuller, the last one comes near to a mystical experience:

\footnotetext{
4 "rozwój ducha [w romantycznej myśli] nie stanowi zamkniętego cyklu w ramach ziemskiej historii. Najistotniejsze jego ogniwo musi być przerzucone w zaświaty, zarówno w dziejach jednostki jako indywidualności, jak i ludzkości." Janion, Romantyzm 143. [translation mine]
} 
"A final stage of lucidity or clairvoyant wisdom," wherein the mind "is temporarily imbued with its omnipresent and omniscient properties. At this deepest level of consciousness, subjects feel themselves to be united with the creative principle of the universe. [...] There is a mystical sense of intimate rapport with the cosmos. Subjects feel that they are in possession of knowledge which transcends that of physical, space-time reality." (9-10)

According to Chu, the tale exemplifies a "genre of consciousness" that she proposes to call "hypnotic ratiocination" (5). By this term she means "a form of exact thinking that operates beyond the opposition between logic and feeling" and which is "inherently dialogic" (Chu 5). She adds that "it is structured like a dialogue between one unconscious participant (who is immersed in the hypnotic experience) and one conscious participant (who remains outside the hypnotic experience and who mediates the dialogue by conducting and recording it)" (Chu 5).

Vankirk - the mastermind and the subject of the experiment in one - in his hypnotic trance on the verge of death describes the spiritual world located in "interstellar space," which, surprisingly, is not a void:

the whole of what we term "space" is to them [the inorganic beings, the angels] the truest substantiality; - the stars, meantime, through what we consider their materiality, escaping the angelic sense, just in proportion as the unparticled matter, through what we consider its immateriality, eludes the organic. (III, 1039)

As Vankirk expounds, human beings in their primitive "organized" condition perceive only the organic life, and angelic beings, as inorganic, have no capacity to recognize the dimensions in which ordinary human life proceeds. The two worlds exist parallel to each other, yet they are related. Tomkowski notices the correlation between the immaterial, spiritual realm, and the earthly, physical plane in heterodox mysticism, the only difference being in the level of perfection attained (20). This fundamental unity of the universe, of all life - characteristic of mystical vision - Tomkowski attributes to its single original constitutive principle, the principle including all spheres of being: spiritual and material, natural, human, and divine (41).

The fundamental unity of all things characterizes also the vision of the universe which unfolds before Vankirk, but here the 
unity results from the materiality of everything that exists, because whatever is immaterial cannot exist, and pure spirit is but an abstraction:

That which is not matter, is not at all - unless qualities are things. [...] But there are gradations of matter of which man knows nothing; the grosser impelling the finer, the finer pervading the grosser [...] These gradations of matter increase in rarity or fineness, until we arrive at a matter unparticled - without particles - indivisible one [...]. (III, 1033)

Poe's unravelling of the unified principles of the universe in "Mesmeric Revelation" and the related "angelic" stories bears much resemblance to German Naturphilosophie and contemporary Romantic science, which, as Chai explains, attempted to reconcile matter with mind in one progressive continuum (6). The American scholar lists here Dalton's atomic theory of matter, Davy's idea of the existence of a single primal substance, and the Laplacean theory of probability (Chai 105).

In Poe's story, a mesmeric trance affords a foretaste of mystical vision, which by its very nature encompasses every aspect of the Creation. Consequently, true to its mystical orientation, "Mesmeric Revelation," after the initial exchange between the hypnotist and the patient, turns into a monologue. This monologue resembles a mystical tract, which aims to explain all, in the vein of Mystical Theology by Dionysius the Areopagite or The Great Mystery by Boehme. As Tomkowski notes, "a mystic is almost never concerned with a portion of reality, he focuses literally on everything. He considers each and every manifestation of existence as worthy of attention, rendering the entire universe without exception a proper subject of inquiry." 5

In his epiphanic enunciation Vankirk goes back to the origin of all things. He declares that "the beginning is GOD," yet in his view, "God with all the powers attributed to spirit, is but the perfection of matter," the "ultimate, or unparticled matter" that "not only

\footnotetext{
5 "mistyk nie interesuje się prawie nigdy wycinkiem rzeczywistości, skupia swą uwage dosłownie na wszystkim. Każdy przejaw egzystencji traktuje jako godny uwagi czyniąc całe bez wyjątku uniwersum właściwym przedmiotem dociekań.” Tomkowski 41. [translation mine]
} 
permeates all things but impels all things - and thus is all things within itself. This matter is God" (III, 1032). Like spirit in the traditional mysticism, this "unparticled" matter is the cause of all motion and of all thought. All things created originate as thoughts in God's mind. Man as an intelligent being is an incarnation of the portion of the divine mind, "for mind, existing unincorporate, is merely God. To create individual, thinking beings, it was necessary to incarnate portions of the divine mind. Thus man is individualized" (III, 1034). Yet the process of creation is irrevocable - a human being cannot become God again.

The universe is inhabited by various "rudimentary" thinking creatures, and the reason for the material universe, as Vankirk explains, is that "of supplying pabulum for the idiosyncrasy of the organs of an infinity of rudimental beings. But for the necessity of the rudimental, prior to the ultimate life, there would have been no bodies such as these" (III, 1038). Thus, the variety of material forms serves to provide stimuli for the senses of organic intelligent beings, which have yet to realize their true destiny - the inorganic or ultimate life. The "primitive," rudimentary condition, the organic life with its various forms and principles, all these are necessary as the impediment to the actions of the unique law - the Divine Volition. Violation of the unique law produces pain, totally absent in the inorganic life, but without the earthly pain, happiness in the ultimate existence would merely be an abstraction. Oppositions and contradictions, which in the earthly experience seem irreconcilable, in Vankirk's vision are presented as inverse and necessary sides of the same process:

Positive pleasure is a mere idea. To be happy at any one point we must have suffered at the same. Never to suffer would have been never to have been blessed. But it has been shown that, in the inorganic life, pain cannot be thus the necessity for the organic. The pain of the primitive life of Earth, is the sole basis of the bliss of the ultimate life in Heaven. (III, 1039)

The hallmark of mystical literature, according to Tomkowski, is the convention that he terms "the letter from the heavens," because it is God who is the "sender" of a spiritual message, and the poet-mystic acts as its "recipient." As the Polish scholar explains: 
a mystical writer puts aside his own personality, and it appears that literary composition becomes possible only with the suspension of the usual activity of human reason. What ensues is a state of a mystical void, which then is interrupted by the movement of the pen impelled by a supernatural power. ${ }^{6}$

As one deriving from this particular source, from an authority "superior to human mind," the resulting mystical work, "the letter received from the heavens," is not subject to verification. It is "God's gift and grace," and "reveals the essence of reality and of the Absolute, uncovers that which is hidden and inaccessible to human reason" (Tomkowski 22).

This convention is also discernible in the examined stories by Poe. In "Mesmeric Revelation," the reality that in the mystical tradition is revealed to inspired visionaries becomes accessible to a dying person put into a hypnotic trance. But it may also be presented from the new, "angelic" perspective of human beings who have crossed the threshold of physical death. As such, their knowledge of the ultimate matters, their authority, cannot be questioned, also because in their present eschatological condition cognition bypasses the fallible senses, limited and liable to distort the image of reality. Things are perceived directly, through a whole "luminous ultimate body" by means of vibrations:

in the ultimate, unorganized life, the external world reaches the whole body [...] with no other intervention than that of an infinitely rarer ether than even the luminiferous; and to this ether - in unison with it - the whole body vibrates. (III, 1038)

In "The Colloquy of Monos and Una," "The Conversation of Eiros and Charmion," and "The Power of Words," the speakers have been enriched by the ordeal of physical death. As Halliburton observes, the experience of death is "heuristic," or epistemological, in nature, as much as ontological (380). From their newly acquired standpoint it turns out to be as much the enlightening experience as the passage to the other side of being. The revelatory nature of death

\footnotetext{
6 "twórca dzieła mistycznego eliminuje zatem własną osobowość, proces tworzenia wydaje się możliwy tylko wtedy, gdy rozum ludzki zawiesza swą aktywność. Następuje stan mistycznej próżni, trwający do chwili, gdy piórem kieruje siła nadprzyrodzona, zacznie ono samo wędrować po papierze." Tomkowski 15. [translation mine]
} 
is affirmed by Charmion, who welcomes Eiros to the heavenly existence after the latter has shaken off the fetters of mortality: "The film of the shadow has already passed from off your eyes" (II, 455). Death, both as a concept and as an experience, turns up very early in the conversation of Monos and Una, variously referred to as "that word which of old was wont to bring terror to all hearts - to throw a mildew upon all pleasures!," "a check to human bliss," or "that evil hour which was hurrying to separate us forever!" (II, 608). Monos also emphasizes the epiphanic dimension of dying: "Death himself resolved for me the secret" (II, 608). The new "inorganic" perspective brings a changed view of death, which no longer signifies loss of consciousness and annihilation of an individual existence, and this entails the revaluation of its tragic implications. As seen from beyond the gulf, Death, as Vankirk asserts in "Mesmeric Revelation," "is but the painful metamorphosis," explaining that "Our future is perfected, ultimate, immortal"; as he puts it, "The ultimate life is the full design" (III, 1037).

In "The Colloquy of Monos and Una" the stages of death are described vividly and in great detail; yet the turning point in the whole process comes when from "the wreck and chaos of all the usual senses" arises "a sixth, all perfect," the sense that enables the mind to perceive "a mental pendulous pulsation [...] the moral embodiment of man's abstract idea of Time" (II, 615). Monos interprets this "keen, perfect, self-existing sentiment of duration," this sentiment existing "independently of any succession of events," this "sixth sense, upspringing from the ashes of the rest," as "the first obvious and certain step of the intemporal soul upon the threshold of the temporal Eternity" (II, 615). Claude Richard notes two kinds of pulsation that "contend for supremacy in Poe's work" "the throbbing of the heart and the essential, cosmic rhythm" (195). As the French scholar explains, the former, the "heart of the hallucinatory other beating audibly in an externalized space spells the cadence of horror and madness," while the latter, "the beating of God's heart," which is "creative of Time," "the soundless essential rhythm," can be heard only after the corporeal senses have been extinguished, and as such it "belongs to the Platonic realm of the intelligible" (Richard 195-196). In Poe's story, this cosmic vibration, permeating the ultimate, inorganic existence, is available to the extra-sensual perception of human beings when crossing the threshold of mortality. 
As Monos explains to Una, in the passage "through the dark Valley and Shadow" of death, all the remaining links with phenomenal reality are finally dissolved. This process is reminiscent of what Richard Jones calls in his study Mysticism Examined the "depth-mystical experience," in which "There is no awareness of any object or of any content of any kind and yet there is still a realization of an ultimate reality," "the experiencer has no sense of differentiation from the reality experienced [...] the mind seems free of content" (2).

In "The Colloquy of Monos and Una," sentience, the consciousness of being, gives way to the sense of duration, and of locality. And with the "dominant and perpetual" reign of the "autocrats Place and Time" (II, 617), the decay is complete. Yet, there is a curious gap between the ending of the story and its beginning, which indicates discontinuity between the final outcome of the dying process and the beginning of a new heavenly existence. What remains of Monos, when he is purged, when he is stripped of all the earthly superfluities, is rendered linguistically by means of paradoxes and contradictions that defy ordinary logic: "that which was not," "that which had no form," "that which had no sentience," "that which had no thought," "that which was soulless, yet of which matter formed no portion," "all this nothingness, yet [...] all this immortality"(II, 617). Halliburton emphasizes the difficulties of Monos as the narrator in representing verbally something that cannot be put into words:

It is neither true that being is any longer material in the usual sense, nor that being is solely spiritual. It is neither true that Monos has ceased to be what he was, nor that he is yet what he will finally become: the state he experiences at the end of the story is precisely intermediate. His situation, in relation to the earth, is a beyond; yet there is another beyond - a still higher sphere of existence - beyond his situation. (Halliburton 385)

Dying thus can be seen as a transition, enacted in the peculiar ontological zone reminiscent of the "betwixt-and-between," the middle stage of the rites of passage, which can be properly called liminal. As Michael Joseph observes, the term liminal and the corresponding noun liminality derive from the Scottish anthropologist Victor Turner, himself influenced by the ethnographical writings on preindustrial societies by Arnold Van Gennep (138). In Turner's 
framework they serve to designate the middle, transitional stage of a three-stage paradigmatic rite of passage (Joseph 138). Roisin O'Gorman defines liminal space as "a transitional place of becoming, a state of flux between two different states of being," and liminality, as she points out, denotes a peculiar condition of the initiate: "a borderland state of ambiguity and indeterminacy, a transformational state characterized by a certain openness and relaxation of rules, leading those who participate in the process to new perspectives and possibilities" (7). The borderland or the threshold zone "holds a promise of growth, change and possibilities that can come into actuality through the ritual processes of transformation" (O'Gorman 11). This can also be observed in Poe's "angelic" stories: the "thing in itself," unnamable, unintelligible, incomprehensible, doomed to slow decay in the grave, eventually metamorphoses into an "inorganic," angelic being, and is reborn to a new existence: the very first words with which Una greets Monos, echoed by him, are "Born again?"

Interestingly, though set in the new, heavenly reality, "The Colloquy of Monos and Una" is tinged by a marked interest in the past: Una burns to know the incidents of her lover's passage through the dark Valley and Shadow, and Monos readily complies with her request. The story details the process of an individual death, and the singularity of the experience is emphasized by the names of the characters, "Una," that is literally "one" in Latin, and "Monos," meaning "single, alone" in Greek. "The Conversation of Eiros and Charmion," its companion piece, also focuses on the recent history the annihilation of the human world at large. Charmion insists on discussing with Eiros the destruction of the earth: "Look not around, nor forward - but back. I am burning with anxiety to hear the details of that stupendous event which threw you among us" (II, 456). The perishing of the world brought about by a "gigantic mantle of rare flame, extending from horizon to horizon," represents, according to Eiros, "the entire fulfilment, in all their minute and terrible details, of the fiery and horror-inspiring denunciations of the prophecies of the Holy Book" (II, 461).

In the presented eschatological vision, the incendiary destruction of all life can be seen as the literary adaptation of the ancient, originally Persian myth of the end of the world, when everything is consumed by fire. As Mircea Eliade points out, strangely enough, in this tradition the end of all things in flames offered comfort and hope: 
fire renews the world, thanks to it a "new world arises, alien to old age, death, decay, decomposition, eternally alive, eternally growing, the dead will be raised, the living achieve immortality - the world will renew itself without end' (The Yasna, XIX, 14, 89, translated into French by Darmsteter). ${ }^{7}$

The horror of the apocalypse is thus defused by the promise of the ensuing bliss, by the expectation of a new, happy, timeless existence.

The characters are given here Latin or Greek names, which strongly indicates the affinity of Poe's "angelic" stories with the Socratic dialogue. According to Halliburton, the philosophical dialogue is a genre especially suitable for rendering a cognitive process; it "is the genre of coming-to-know," in which "the direction of the argument is determined by one whose knowledge is superior" (380). The impetus is provided by the wiser person; therefore, the dialogue serves as a tool for raising a less advanced being to a higher level of understanding (Halliburton 380). In Poe's "angelic dialogues," the reborn beings act like faithful disciples, eager to be initiated into the mysteries of the ultimate life. Accordingly, Charmion promises to Eiros: "tomorrow, I will myself induct you into the full joys and wonders of your novel existence" (II, 455). In "The Power of Words," the newly arrived Oinos is greeted by Agathos, who acts as his mentor and guide to the heavenly existence. Oinos is the namesake of the protagonist-narrator of the story Shadow - A Parable, whose memorable lines reach the reader across the abyss of death: "YE who read are still among the living: but I who write shall have long since gone my way into the region of shadows" (II, 188). In "The Power of Words," Oinos, "a spirit new-fledged with immortality," craves knowledge of "all things" and asks Agathos "to instruct [him]! speak to [him] in the earth's familiar tones!" (III, 1212) Agathos indeed assumes the role of a wise and experienced teacher; he unravels before Oinos the secrets of the Creation: "Let me endeavor, my Oinos, to lead you step by step, to the conception I intend" (III, 1213). It is in this story that the ultimate destiny of man is finally unfolded - the vision of existence free from the tragic, released from

\footnotetext{
7 "W istocie - ogień odnawia świat, dzięki niemu powstanie 'świat nowy, odjęty starości, śmierci, rozkładowi i zgniliźnie, wiecznie żywy, wiecznie rosnący, kiedy to martwi powstana, żywi dostąia nieśmiertelności, a świat odnawiać się będzie do woli' (Jaszt, XIX, 14, 89, wg. tłum. Darmstetera). Eliade 284. [translation mine].
} 
the bounds of mortality and temporality, unencumbered by the imperfect corporeal senses.

Quite relevantly, in his discussion of Poe's "Al Aaraaf" William Engel mentions the poet's fascination with the period's doctrine of stellification, a Renaissance revival of the older view of an afterlife in the stars, through a transformation into stellar or angelic substance after death (84). In the reality presented in Poe's "mystical" stories, metamorphosed human beings in their "stellified" condition experience the infinite expanse of the heavens directly, through their "luminous bodies." In this newly perceived realm, all thought is creative and its effect manifests itself immediately.

Yet, contrary to Oinos's dream that in this ultimate existence he "should be at once cognizant of all things, and thus at once happy in being cognizant of all" (III, 1212), as Agathos patiently explains, cognition is in fact an endless process, because true happiness lies in acquiring knowledge, not in knowing all: "In for ever knowing, we are for ever blessed" (III, 1212). The infinity of the universe corresponds to the infinite cognitive yearnings of the soul: its "sole purpose is to afford infinite springs, at which the soul may allay the thirst to know which is for ever unquenchable within it - since to quench it, would be to extinguish the soul's self" (III, 1212).

The expansion of metaphysical and spiritual elements in the examined stories is counterpointed by the attenuation of the plot. Poe's "post-mortem reveries," rather than creating the fictional reality, describe and explain I; thus, the action is replaced by rhetoric. The intensifying mystical strains with the concomitant reduction of narrative find their culmination in "Eureka," which is free from any fictionality whatsoever. Elizabeth Vincelette, in her article "Beauty, Truth, and the Word: The Prophecy and Theology of Poe's Eureka," calls Poe's treatise his "most ardent appeal to bring his audience to his vision of truth," a cosmology "based upon ancient and contemporary philosophers and astronomers in a blend of poetry, mathematics, and metaphysics" (36). However, this singular "Prose Poem" has drawn a vast amount of scholarly attention and there is little that can be added here as a supplement. Besides, a more extensive examination of this work would exceed the limits of the present article, whose aim has been to bring out the mystical aspects of the stories less frequently studied in numinotic terms or hardly at all associated with mysticism.

In "A Descent into the Maelström" the narrative circumstances encompassing the soaring rocky cliff and the sea abyss recall the 
spiritual and mystical tradition that locates a theophany or divine illumination on a mountain top. The initiatory pattern established in this story recurs in the Dupin tales, in which the detective assumes the role of a brilliant and informed master, and the narrator is his eager disciple. These tales of detection are also marked for the revalorization of darkness. Rather than the source of terror and oppression, as in "The Pit and the Pendulum," darkness becomes conducive to enlightenment, which is reminiscent of the "night of the soul" almost obligatorily preceding illumination in the Western mystical tradition. In the landscape tales, a transcendent vision is embodied in the material world, and the resulting elevation of the physical realm affords a glimpse of a higher, spiritual reality, calling to mind "the justification of nature," a new trend in heterodox mysticism that developed in Germany in the sixteenth and seventeenth century. In "Mesmeric Revelation," insight into an extramundane reality is achieved thanks to hypnosis. A mesmeric trance at its deepest stage resembles a mystical experience, and Vankirk's monologue, much like a mystical tract, encompasses every aspect of the Creation. This is in stark contrast with the story with a similar theme, "Facts in the Case of M. Valdemar," where the only message delivered from the Other Side is "I am dead," and which ends with the revolting image of a rapidly decomposing body.

Mystical explorations in "Mesmeric Revelation" aim at unravelling the unified principles of the universe, exposing the fundamental unity of all things, while "The Colloquy of Monos and Una," "The Conversation of Eiros and Charmion," and "The Power of Words" all revolve around post-mortem initiation into the secrets of a new, spiritual existence. These revelations are presented from the "angelic" perspective of human beings who have crossed the threshold of physical death. Additionally, the incendiary destruction of the earth depicted in "The Conversation of Eiros and Charmion" can be regarded as the reenactment of the purification by fire of the old and decaying world, the adaptation of the eschatological motif derived from the Persian myth.

These tropes and allusions surfacing in the examined tales demonstrate that Poe's fiction deeply resonates with the ancient esoteric and spiritual traditions. And tracing the sometimes quite oblique references to Western mystical literature, orthodox and heterodox, certainly puts the familiar stories in a new and, hopefully, quite revelatory perspective. 


\section{WORKS CITED}

AGUIRRE, Manuel. "Geometries of Terror: Numinous Spaces in Gothic, Horror and Science Fiction." Gothic Studies, Vol. 10, No. 1, 2008, pp. $1-18$.

CASALE, Ottavio M. "Poe on Transcendentalism." A Journal of American Renaissance, Vol. 50, No. 1, 1968, pp. 85-97.

CHAI, Leon. The Romantic Foundations of the American Renaissance. Cornell University Press, 1987.

CHU, Seo-Young Jennie. "Hypnotic Ratiocination." The Edgar Allan Poe Review, Vol. 6, No. 1, 2005, pp. 5-19.

CLACK, Randall A. “Strange Alchemy of Brain': Poe and Alchemy.” A Companion to Poe Studies, edited by E. Carlson, Greenwood Press, 1996, pp. 367-387

COX, Jeffrey. In the Shadows of Romance: Romantic Tragic Drama in Germany, England, and France. Ohio University Press, 1987.

ELIADE, Mircea. Sacrum, mit, historia. PIW, 1993.

ELIADE, Mircea. History of Religious Ideas, Volume 1: From the Stone Age to the Eleusinian Mysteries. Translated by W. Trask, The University of Chicago Press, 1978.

ENGEL, William E. Early Modern Poetics in Melville and Poe. Memory, Melancholy, and the Emblematic Tradition. Ashgate Publishing, 2012.

GRANT, Patrick. Literature of Mysticism in Western Tradition. The Macmillan Press Ltd., 1983

GRIFFITH, Clark. "Poe's 'Ligeia' and the English Romantics." University of Toronto Quarterly, Vol. 24, No. 1, 1954, pp. 8-25.

HALliBURTON, David. Edgar Allan Poe. A Phenomenological View. Princeton University Press, 1973.

JAMES, William. The Varieties of Religious Experience. Edited and With an Introduction by Martin E. Marty. Penguin Books, 1986

JANION, Maria. Czas formy otwartej. PIW, 1984. 
JANION, Maria. Romantyzm. Studia o ideach i stylu. PWN, 1969.

JOSEPH, Michael. "Liminality." Keywords for Children's Literature. Edited by P. Nel and L. Paul, New York University Press, 2011, pp. 138-140.

JONES, Richard H. Mysticism Examined: Philosophical Inquiries into Mysticism. State University of New York Press. 1993.

JONES, Rufus M. Spiritual Reformers in the 16th and 17th Centuries. Bible Hub, https://biblehub.com/library/jones/spiritual_reformers_in_the_16th_ and_17th_centuries/index.html. Accessed 20 August 2018.

KETTERER, David. The Rationale of Deception in Poe. Louisiana State University Press, 1979.

KOPALIŃSKI, Władysław. Słownik wyrazów obcych $i$ zwrotów obcojęzycznych. Wiedza Powszechna, 1989.

KOPLEY, Richard. Edgar Allan Poe and the Dupin Mysteries. Palgrave Macmillan, 2008.

LEVINE, Stuart. Edgar Poe: Seer and Craftsman. Everet Edwards Inc., 1973.

LOWELL, James Russell. (1845). "Our Contributors-No. XVII. Edgar Allan Poe." Edgar Allan Poe: The Critical Heritage, edited by Ian Walker, Taylor \& Francis e-Library, 2002, pp. 156-167.

MABBOTT, Thomas Olive. The Collected Works of Edgar Allan Poe, Vol. II and Vol. III. Belknap Press of Harvard University Press, 1978.

MCGANN, Jerome. The Poet Edgar Allan Poe: Alien Angel. Harvard University Press. 2014.

O'GORMAN, Roisin. "Caught in the Liminal: Dorothy Cross's Udder Series and Marina Carr's By the Bog of Cats..." Liminal Borderlands in Irish Literature and Culture, edited by I. G. Nordin and E. Holmsten, Peter Lang, 2009, pp. 103-130.

PEYRE, Henri. Co to jest romantyzm? PWN, 1987.

RICHARD, Claude. "The Heart of Poe and the Rhythmics of the Poems." Critical Essays on Edgar Allan Poe, edited by Eric W. Carlson, G. K. Hall \& Co, 1987, pp. 195-206. 
ROMERO, Dolores. "El transfondo ocultista del cuervo: desde su simbolismo poético a los topoi modernistas." Ilu. Revista de Ciencias de las Religiones, Vol. 18, No. 1, 2013, pp. 201-218.

SILVERMANN, Kenneth. "Introduction." New Essays on Poe's Major Tales, edited by K. Silvermann, Cambridge University Press, 1995, pp. 1-26.

SIMMS, William Gilmore. (1845). "From an editorial review." Edgar Allan Poe: The Critical Heritage, edited by Ian Walker, Taylor \& Francis e-Library, 2002,pp.200-201.

SWEEnEY, Gerard M. "Beauty and Truth: Poe's 'A Descent into the Maelstrom.” Poe Studies, Vol. 6, No. 1, 1973, pp. 22-25.

THOMPSON, G. R. "Note on the Texts." Edgar Allan Poe. Essays and Reviews, edited by G. R. Thompson, Library of America, 1984, pp. 1482-1493.

TOMKOWSKI, Jan. Juliusz Słowacki i tradycje mistyki europejskiej. PIW, 1984.

WILDE, DANA. "Poe's Mysticism and the Eureka." Research Gate, June 2005,http://doi.org/10.13140/RG.2.1.2086.4160.

VINCELETTE, Elizabeth. "Beauty, Truth, and the Word: The Prophecy and Theology of Poe's Eureka." The Edgar Allan Poe Review, Vol. 9, No. 2, 2008, pp. 36-54. 